\title{
Steroid-sparing agents for the treatment of inflammation in complicated neurocysticercosis
}

\author{
Pria Anand, MD, Shibani S. Mukerji, MD, PhD, Jesse Thon, MD, Shauna Gunaratne, MD, MPH, \\ Tracey A. Cho, MD, and Nagagopal Venna, MD
}

Neurol Neuroimmunol Neuroinflamm 2019;6:e606. doi:10.1212/NXI.0000000000000606

\author{
Correspondence \\ Dr. Anand \\ pria.anand@gmail.com
}

Neurocysticercosis (NCC) is a major cause of neurologic disease and epilepsy worldwide. Clinical manifestations of NCC are primarily due to the inflammatory response against degenerating cysts of the Taenia solium tapeworm, which occurs when cysts lose their ability to evade host immune responses. Patients with subarachnoid or severe parenchymal NCC may also develop chronic inflammation requiring long-term immunosuppression. ${ }^{2}$

Corticosteroids are first-line anti-inflammatory agents in NCC; however, prolonged treatment is associated with multiorgan toxicity. While recent guidelines recommend methotrexate (MTX) as a steroid-sparing agent (SSA), when to initiate SSAs and alternatives to MTX in the case of failure or intolerance remain unspecified. ${ }^{1}$ Here, we describe 3 patients followed at a single hospital for NCC-associated inflammation requiring SSAs.

\section{Patient 1}

A 64-year-old Cape Verdean woman presented with headaches, seizures, and multiple subarachnoid cysts on brain MRI (figure 1A) with a positive CSF cysticercal antigen. She had communicating hydrocephalus requiring a 3rd ventriculostomy and subsequent ventriculoperitoneal (VP) shunt and was treated with albendazole and prednisone 20-60 mg daily for 24 months because of persistent headaches and subarachnoid cysts on MRI. She experienced a clinical and radiographic relapse following prednisone taper over 18 weeks. CSF analysis showed a negative cysticercal antigen. Weekly MTX $7.5 \mathrm{mg}$ was tried but resulted in ulcerative stomatitis and leukopenia. Prednisone $60 \mathrm{mg}$ daily was resumed without antiparasitic therapy and was tapered over 10 months with resolution of her symptoms and MRI findings (figure 1B).

\section{Patient 2}

A 48-year-old Guatemalan man presented with headaches, falls, and multiple cysts in the prepontine and lumbar cisterns (figure $1, C$ and D) and 4th ventricle. He underwent removal of the intraventricular cyst and placement of a VP shunt and was treated with albendazole and dexamethasone 4-6 mg daily for 6 months because of persistent leptomeningeal enhancement, headaches, and a 6th cranial nerve palsy. He ran out of medication and returned 1 month later with vertigo. He resumed dexamethasone for 6 additional months, complicated by lumbar vertebral fracture. Because of persistent inflammation identified on his brain MRI, he was transitioned to MTX $7.5 \mathrm{mg}$ weekly with clinical stability for 5 months.

\footnotetext{
From the Division of Neuroimmunology and Neuro-Infectious Diseases (P.A., S.S.M., N.V.), Department of Neurology, Massachusetts General Hospital, Boston; Department of Neurology (J.T.), University of Pennsylvania, Philadelphia; Division of Infectious Diseases (S.G.), Massachusetts General Hospital, Boston; and Division of Neuroimmunology (T.A.C.), Department of Neurology, University of lowa. 
Figure MRI findings in complicated NCC

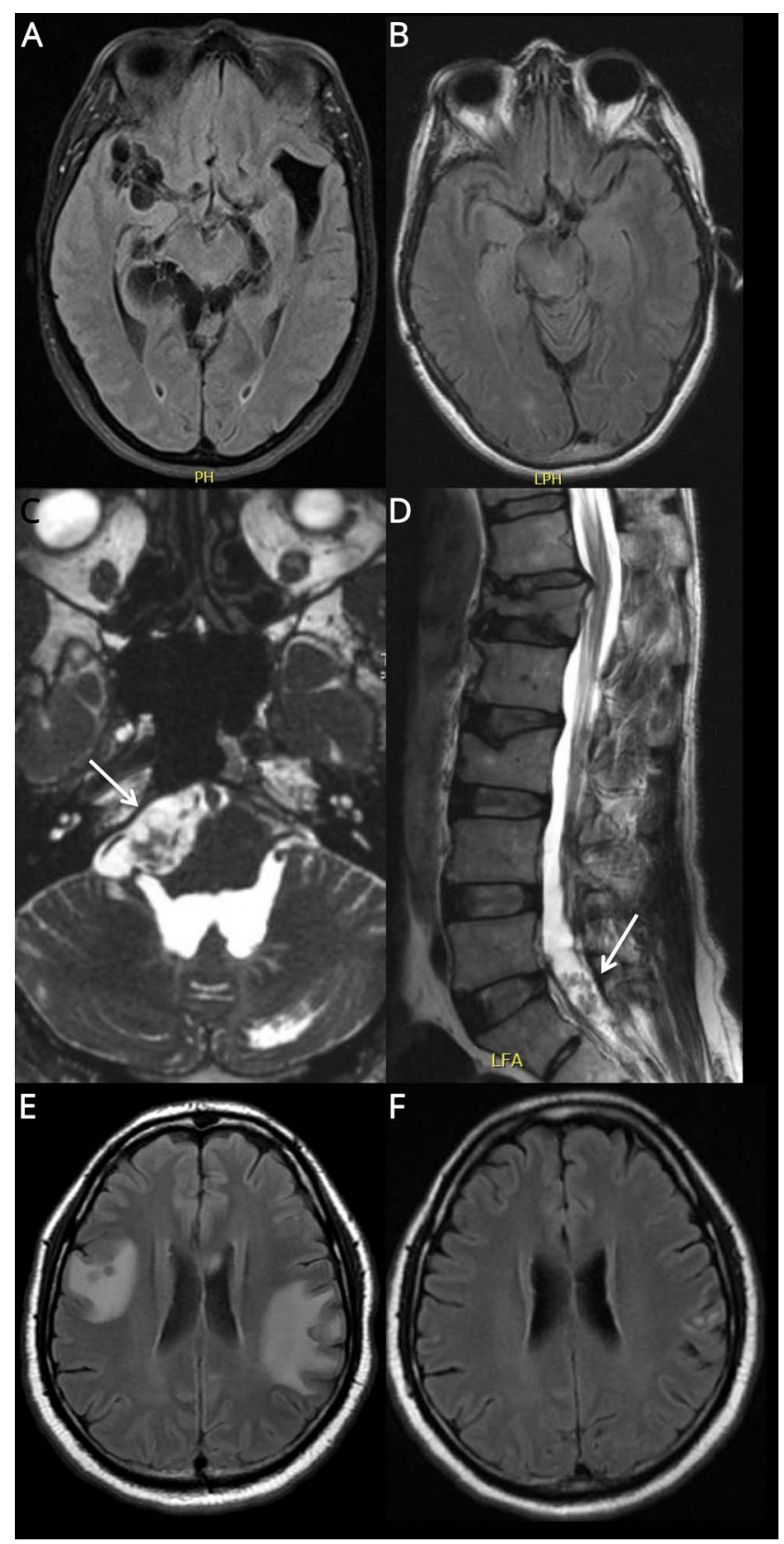

Patient 1: T2-weighted FLAIR sequences on MRI brain show (A) subarachnoid cysts in the basilar, perimesencephalic, quadrigeminal, and perisylvian cisterns prior to treatment and (B) resolution of cystic lesions after treatment with corticosteroids. Patient 2: Highly T2-weighted fast imaging employing steady-state acquisition sequences on MRI brain and T2-weighted sequences on MRI spine show cystic lesions of (C) prepontine and (D) sacral cisterns. Patient 3: T2-weighted FLAIR sequences on MRI brain show (A) extensive perilesional edema in spite of MTX and corticosteroid therapy and (B) marked improvement in perilesional edema following the addition of adalimumab. FLAIR = fluid-attenuated inversion recovery; NCC = neurocysticercosis.

\section{Patient 3}

A 43-year-old Cape Verdean man presented with headache, aphasia, and parenchymal cysts with surrounding edema identified on brain MRI. He was treated with a 14-day course of praziquantel, albendazole, and dexamethasone $6 \mathrm{mg}$ daily followed by a dexamethasone taper. Two months later, he returned with headaches, seizures, and new perilesional edema. He was re-treated with albendazole and praziquantel for 14 days with prednisone $50 \mathrm{mg}$ daily, complicated by avascular necrosis of the hip. Because of the ongoing perilesional edema on high-dose prednisone, he initiated MTX with a maximum dose of $20 \mathrm{mg}$ weekly. Perilesional edema persisted on MTX and high-dose prednisone (figure 1E), and he was started on adalimumab $50 \mathrm{mg}$ every 14 days with clinical and radiographic resolution (figure $1 \mathrm{~F}$ ). MTX and prednisone were tapered over 16 weeks without recurrence. His seizures and headaches returned during a 6-week interruption in adalimumab treatment and resolved with reinitiation.

\section{Discussion}

While use of anti-inflammatory agents is common practice in NCC treatment, limited data exist on the transition from corticosteroids to SSAs. Here, we describe 3 cases of persistent NCC-associated inflammation that highlight both the efficacy and complications of SSA use in NCC.

Treatment of chronic perilesional edema with corticosteroids can be associated with rebound inflammation in the setting of corticosteroid taper. ${ }^{3}$ Two prior case series have described the successful use of MTX in controlling perilesional edema and facilitating corticosteroid discontinuation, ${ }^{2,4}$ supported by the clinical course of patient 2. By contrast, patients 1 and 3 highlight challenges posed by MTX toxicity or failure.

Tumor necrosis factor alpha (TNF- $\alpha$ ) is an important modulator of inflammation, and elevated levels of CSF TNF- $\alpha$ have been found in patients with subarachnoid NCC. ${ }^{5}$ In a pig model of parenchymal NCC, TNF- $\alpha$ expression was increased following antiparasitic therapy. In the same model, pretreatment with etanercept, a TNF- $\alpha$ inhibitor, led to reduced TNF- $\alpha$ levels after antiparasitic therapy, suggesting that TNF- $\alpha$ may be an appropriate target in persistent NCC-associated inflammation. ${ }^{6}$ Patient 3 in our series showed dramatic improvement on adalimumab following MTX and corticosteroid failure. To our knowledge, there is only one published case series of TNF- $\alpha$ use in human patients with NCC. ${ }^{7}$ Our findings reinforce that TNF- $\alpha$ inhibitors are effective in treating chronic inflammation in NCC.

Though limited by the small number of patients, our series emphasizes the need for further studies on the use of SSAs in the treatment of NCC-related inflammation. Future guidelines should consider TNF- $\alpha$ inhibitors as part of the repertoire of anti-inflammatory therapies in NCC.

\section{Study funding}

No targeted funding reported. 


\section{Disclosure}

P. Anand, S. Mukerji, J. Thon, S. Gunaratne, T. Cho, and N. Venna report no disclosures. Go to Neurology.org/NN for full disclosures.

\section{Publication history}

Received by Neurology: Neuroimmunology \& Neuroinflammation May 20, 2019. Accepted in final form July 52019.

\section{Appendix Authors}

\begin{tabular}{llll}
\hline Name & Location & Role & Contribution \\
\hline $\begin{array}{l}\text { Pria Anand, } \\
\text { MD }\end{array}$ & $\begin{array}{l}\text { Massachusetts } \\
\text { General } \\
\text { Hospital }\end{array}$ & Author & $\begin{array}{l}\text { Data acquisition, drafting/ } \\
\text { revising the manuscript, } \\
\text { study concept or design, } \\
\text { analysis or interpretation of } \\
\text { data, and acquisition of data }\end{array}$ \\
\hline $\begin{array}{l}\text { Shibani S. } \\
\text { Mukerji, }\end{array}$ & $\begin{array}{l}\text { Massachusetts } \\
\text { General } \\
\text { Hospital }\end{array}$ & Author & $\begin{array}{l}\text { Data acquisition, drafting/ } \\
\text { revising the manuscript, } \\
\text { study concept or design, and } \\
\text { analysis or interpretation of } \\
\text { data }\end{array}$ \\
$\begin{array}{l}\text { Jesse Thon, } \\
\text { MD }\end{array}$ & $\begin{array}{l}\text { University of } \\
\text { Pennsylvania }\end{array}$ & Author & $\begin{array}{l}\text { Drafting/revising the } \\
\text { manuscript }\end{array}$ \\
\hline $\begin{array}{l}\text { Shauna } \\
\text { Gunaratne, } \\
\text { MD, MPH }\end{array}$ & $\begin{array}{l}\text { Massachusetts } \\
\text { General } \\
\text { Hospital }\end{array}$ & Author & $\begin{array}{l}\text { Data acquisition, drafting/ } \\
\text { revising the manuscript, and } \\
\text { analysis or interpretation of } \\
\text { data }\end{array}$ \\
\hline
\end{tabular}

Appendix (continued)

\begin{tabular}{llll}
\hline Name & Location & Role & Contribution \\
\hline $\begin{array}{l}\text { Tracey A. } \\
\text { Cho, MD }\end{array}$ & $\begin{array}{l}\text { University of } \\
\text { lowa }\end{array}$ & Author & $\begin{array}{l}\text { Data acquisition, drafting/ } \\
\text { revising the manuscript, } \\
\text { study concept or design, and } \\
\text { analysis or interpretation of } \\
\text { data }\end{array}$ \\
\hline $\begin{array}{l}\text { Nagagopal } \\
\text { Venna, MD }\end{array}$ & $\begin{array}{l}\text { Massachusetts } \\
\text { General } \\
\text { Hospital }\end{array}$ & Author & $\begin{array}{l}\text { Data acquisition, drafting/ } \\
\text { revising the manuscript, } \\
\text { study concept or design, and } \\
\text { study supervision }\end{array}$ \\
\hline
\end{tabular}

\section{References}

1. White AC, Coyle CM, Rajshekhar V, et al. Diagnosis and treatment of neurocysticercosis: 2017 clinical practice guidelines by the Infectious Diseases Society of America (IDSA) and the American Society of Tropical Medicine and Hygiene (ASTMH). Am J Trop Med Hyg 2018;66:1159-1163.

2. Keiser PB, Nash TE. Prolonged perilesional edema after treatment of parenchymal neurocysticercosis: methotrexate as a corticosteroid sparing agent. Clin Infect Dis 2003;36:e122-e126.

3. Mejia R, Nash TE. Corticosteroid withdrawal precipitates perilesional edema around calcified Taenia solium cysts. Am J Trop Med Hyg 2013;89:919-923.

4. Mitre E, Talaat KR, Sperling MR, Nash TE. Methotrexate as a corticosteroid- sparing agent in complicated neurocysticercosis. Clin Infect Dis 2007;44:549-553.

5. Aguilar-Rebolledo F, Cedillo-Rivera R, Llaguno-Violante P, Torres-López J, MuñozHernandez O, Enciso-Moreno JA. Interleukin levels in cerebrospinal fluid from children with neurocysticercosis. Am J Trop Med Hyg 2001;64:35-40.

6. Mahanty S, Orrego MA, Cangalaya C, et al. TNF- blockade suppresses pericystic inflammation following anthelmintic treatment in porcine neurocysticercosis. PLoS Negl Trop Dis 2017;11:e0006059.

7. Nash TE, Ware JAM, Coyle CM, Mahanty S. Etanercept to control inflammation in the treatment of complicated neurocysticercosis. Am J Trop Med Hyg 2019;100:609-616. 


\title{
Neurology ${ }^{\oplus}$ \\ Neuroimmunology \& Neuroinflammation
}

\author{
Steroid-sparing agents for the treatment of inflammation in complicated \\ neurocysticercosis \\ Pria Anand, Shibani S. Mukerji, Jesse Thon, et al. \\ Neurol Neuroimmunol Neuroinflamm 2019;6; \\ DOI 10.1212/NXI.0000000000000606
}

This information is current as of August 20, 2019

Neurol Neuroimmunol Neuroinflamm is an official journal of the American Academy of Neurology.

Published since April 2014, it is an open-access, online-only, continuous publication journal. Copyright

Copyright $\left({ }^{\circ} 2019\right.$ The Author(s). Published by Wolters Kluwer Health, Inc. on behalf of the American

Academy of Neurology.. All rights reserved. Online ISSN: 2332-7812.

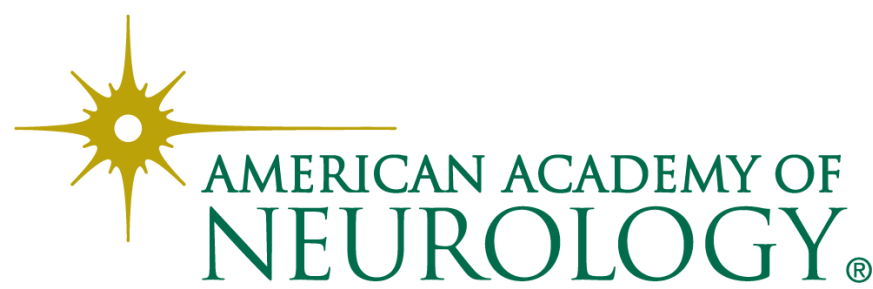




\section{Updated Information \& Services}

References

Citations

Subspecialty Collections

Permissions \& Licensing

Reprints including high resolution figures, can be found at:

http://nn.neurology.org/content/6/6/e606.full.html

This article cites 7 articles, 2 of which you can access for free at: http://nn.neurology.org/content/6/6/e606.full.html\#\#ref-list-1

This article has been cited by 1 HighWire-hosted articles: http://nn.neurology.org/content/6/6/e606.full.html\#\#otherarticles

This article, along with others on similar topics, appears in the following collection(s):

All Clinical Neurology

http://nn.neurology.org//cgi/collection/all_clinical_neurology All Immunology

http://nn.neurology.org//cgi/collection/all_immunology

All Infections

http://nn.neurology.org//cgi/collection/all_infections

Parasitic infections

http://nn.neurology.org//cgi/collection/parasitic_infections

Post-infectious

http://nn.neurology.org//cgi/collection/postinfectious_

Information about reproducing this article in parts (figures,tables) or in its entirety can be found online at:

http://nn.neurology.org/misc/about.xhtml\#permissions

Information about ordering reprints can be found online:

http://nn.neurology.org/misc/addir.xhtml\#reprintsus

Neurol Neuroimmunol Neuroinflamm is an official journal of the American Academy of Neurology.

Published since April 2014, it is an open-access, online-only, continuous publication journal. Copyright

Copyright $\odot 2019$ The Author(s). Published by Wolters Kluwer Health, Inc. on behalf of the American

Academy of Neurology.. All rights reserved. Online ISSN: 2332-7812.

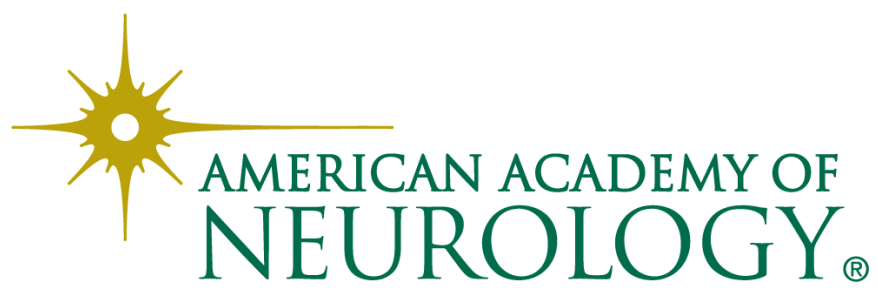

